\title{
Agronomic characteristics and nutritive value of elephant grass clones managed under rotational stocking during the dry period
}

\section{Características agronômicas e valor nutritivo de clones de capim- elefante manejados sob lotação rotacionada no período seco}

\author{
Danilo Antonio Morenz ${ }^{1}$; Mirton José Frota Morenz²; Domingos Sávio Campos \\ Paciullo $^{2 *}$; Carlos Augusto de Miranda Gomide ${ }^{2}$; Francisco José da Silva Lédo²; \\ Fernando César Ferraz Lopes ${ }^{3}$
}

\begin{abstract}
This study aimed to evaluate the agronomic characteristics and nutritional value of two clones of elephant grass (CNPGL 00-1-3 and BRS Kurumi) operating under rotational stocking in the dry season. A completely randomized design with repeated measures (grazing cycles) and three replicates (paddocks) was used. Clones were managed under rotational stocking with a defoliation interval of 24 days and four days of occupation of paddocks, using Holstein x Gyr heifers with mean body weight of 150 $\mathrm{kg}$. The evaluations were conducted in April/May, May/June, June/July and July/August 2010. Green forage mass was influenced by clone and grazing cycle, with higher mean value observed for CNPGL 03-01-00, which was 17\% higher than the value observed for BRS Kurumi, and there was decreased of dry mass of green forage with the advance of grazing cycles. Leaf mass was influenced only by grazing cycle, with gradual reduction from the first to the third cycle. However, in fourth cycle was increase in biomass of leaves, which did not differ from that observed in the second cycle. There was interaction for dry matter production of stem, being observed differences in the first and third cycles for the clones. There was no effect of the factors studied for the production of senescent material. The leaf:stem ratio was influenced by grazing cycles, with interaction of the factors studied. The clone BRS Kurumi kept the leaf:stem ratio stable over the cycles, while clone CNPGL 1-3-00 presented a decrease in leaf:stem ratio from first until to third cycle. The content of crude protein $(\mathrm{PB})$ was not influenced by the factors studied, with average values of $15.3 \%$ and $15.8 \%$ PB for the CNPGL 00-1-3 and BRS Kurumi clones. Neutral detergent fiber (NDF) and the in vitro dry matter digestibility (IVDMD) were affected only by grazing cycles. The highest values of NDF were observed in the three first grazing cycles, with values of $55.5 \%, 56.0 \%$ and $55.7 \%$ from the first to the third grazing cycle, respectively, while in the fourth cycle was obtained the value of $50.5 \%$. There was a decrease in the IVDMD until the third cycle. In the fourth cycle the IVDMD values were similar to the first cycle. The clones did not differ in relation to biomass production, morphological composition and nutritional value, during the dry season.
\end{abstract}

Key words: Chemical composition. Crude protein. Forage mass. Morphological composition.

1 Dr. em Zootecnia, Instituto de Zootecnia, Universidade Federal Rural do Rio de Janeiro, UFRRJ, Seropédica, RJ, Brasil. E-mail: danilo.morenz@gmail.com.br

2 Pesquisadores, Empresa Brasileira de Pesquisa Agropecuária, EMBRAPA Gado de Leite, Juiz de Fora, MG, Brasil. E-mail: mirton.morenz@embrapa.br; domingos.paciullo@embrapa.br; carlos.gomide@embrapa.br; francisco.ledo@embrapa.br

3 Analista, EMBRAPA Gado de Leite, Juiz de Fora, MG, Brasil. E-mail: fernando.lopes@embrapa.br

* Author for correspondence 


\section{Resumo}

Objetivou-se avaliar as características agronômicas e o valor nutricional de clones de capim-elefante sob lotação rotacionada. Foram avaliados os clones CNPGL 00-1-3 e BRS Kurumi, distribuídos em delineamento inteiramente casualizado, com medidas repetidas no tempo (ciclos de pastejo) e três repetições (piquetes). Foram utilizadas 16 novilhas Holandês x Gir, com peso corporal médio inicial de $150 \mathrm{~kg}$. Animais reguladores de consumo foram utilizados, quando necessário, para o alcance das metas de manejo. Os clones foram manejados sob lotação rotacionada, com 24 dias de intervalo de desfolha e quatro dias de ocupação dos piquetes. As avaliações foram conduzidas em abril/maio, maio/junho. Junho/julho e lulho/agosto de 2010. O valor médio da massa seca de forragem verde do CNPGL 00-1-3 foi $17 \%$ maior do que a do BRS Kurumi. Com o avançar dos ciclos de pastejo houve redução da massa seca de forragem verde. A biomassa seca de folha foi influenciada apenas pelo ciclo de pastejo, com redução gradual do primeiro até o terceiro ciclo. No quarto ciclo houve aumento na massa seca de folha, que não diferenciou daquela obtida no segundo ciclo. Houve interação clone x ciclo para a massa de colmo, sendo observadas diferenças entre clones apenas no primeiro e terceiro ciclos. Não houve efeito dos fatores estudados ou da interação para a massa seca de material morto. O BRS Kurumi manteve a relação folha:colmo estável ao longo dos ciclos, enquanto que o CNPGL 00-1-3 apresentou decréscimo nesta variável do primeiro até o terceiro ciclo, com maior valor obtido no quarto ciclo. Não houve efeito dos fatores estudados sobre os teores de proteína bruta, com valores médios de $15,3 \%$ e $15,8 \%$, respectivamente, para CNPGL 00-1-3 e BRS Kurumi. Os teores de fibra em detergente neutro (FDN) e os coeficientes de digestibilidade in vitro da matéria seca (DIVMS) foram influenciados apenas pelos ciclos de pastejo. Maiores valores de FDN foram observados nos três primeiros ciclos de pastejo, sendo obtidos teores de $55,5 \%, 56,0 \%$ e $55,7 \%$ do primeiro ao terceiro ciclo de pastejo, respectivamente, enquanto que no quarto ciclo observou-se $50,5 \%$ de FDN. Houve queda da DIVMS até o terceiro ciclo. No quarto ciclo as DIVMS foram semelhantes às do primeiro ciclo. Concluindo, os clones não diferiram entre si em relação à produção de biomassa, folha:colmo e valor nutritivo.

Palavras-chave: Composição morfológica. Composição química. Massa de forragem. Proteína bruta.

\section{Introduction}

Milk production systems in Brazil are mostly based on the use of tropical grass pasture as the main source of nutrients for animals. Therefore, the productive and economic efficiencies of milk production systems are directly related to the formation and management of productive pastures in order to obtain forage of high nutritive value. The maintenance of high levels of meat or milk production under grazing conditions involves challenges such as the maintenance of forage with respect to quantity and quality, prolongation of the grazing season in the dry period, adequate use of concentrated supplements, and definition of the management strategy aimed at increasing milk production by area. Thus, in order to fill the gaps of grazing production systems, the development of new forage cultivars can contribute even more to the growth and competitiveness of Brazilian livestock production systems, and it is necessary to evaluate and characterize these new cultivars.

Elephantgrass (Pennisetum purpureum Schum.) is recognized for its biomass production rate and nutritional value and is cultivated throughout Brazil (QUEIROZ FILHO et al., 2000; DERESZ et al., 2006). However, the difficulty in obtaining adequate structure of vegetation due to the high elongation of stems, especially under intensive grazing, is one of the main limitations of using elephantgrass in grazing systems. This stems elongation results in reduction of leaf:stem ratio, grazing efficiency and, consequently, forage nutritive value (PACIULLO et al., 2003; CARVALHO et al., 2005).

In this context, the Embrapa Gado de Leite, in partnership with other research and teaching 
institutions in Brazil, developed two small-sized elephantgrass clones (CNPGL 00-1-3 and BRS Kurumi) that are characterized by high productive potential and nutritional value of the forage (CHAVES et al., 2016). These clones also facilitate their management due to a reduced stem elongation rate (FERNANDES et al., 2016).

Knowledge of the characteristics of these clones during the dry season is important as a way of establishing management strategies for maximum efficiency of pastures. Thus, the objective of this study was to evaluate the biomass production, the leaf:stem ratio and the nutritive value of two smallsized elephantgrass clones managed under rotational stocking during the dry season.

\section{Materials and Methods}

This experiment was carried out at the Experimental Farm of Embrapa Dairy Cattle located in Valença, Minas Gerais State, Brazil during the dry season of the year (April to August 2010). The geographical coordinates are $22^{\circ} 21^{\prime}$ south latitude, $43^{\circ} 42^{\prime}$ west longitude, and the altitude of the site is $446 \mathrm{~m}$. The climate is a Cwa type (mesothermal) according to the Köppen classification system. Climate data were collected from a meteorological station located approximately $1,000 \mathrm{~m}$ from the experimental area (Figure 1). The soil in the experimental area is classified as Regolytic Neosol (EMBRAPA, 2006). The chemical characteristics of the soil are as follows: $\mathrm{pH}\left(\mathrm{H}_{2} \mathrm{O}\right)=5.7 ; \mathrm{P}=10.5 \mathrm{mg}$ $\mathrm{dm}^{-3} ; \mathrm{K}=171.0 \mathrm{mg} \mathrm{dm}^{-3} ; \mathrm{H}++\mathrm{Al}^{+3}=3.4 \mathrm{cmolc} \mathrm{dm}^{-}$ 3; $\mathrm{Ca}^{+2}=2.7 \mathrm{cmolc} \mathrm{dm}^{-3} ; \mathrm{Mg}^{+2}=1.4 \mathrm{cmolc} \mathrm{dm}^{-3} ; \mathrm{V}$ $=57,0 \%$ and $\mathrm{OM}=1.8{\mathrm{dag} \mathrm{kg}^{-1}}^{-}$.

Figure 1. Precipitation and temperature maximum, minimum and mean registered during the trial period.

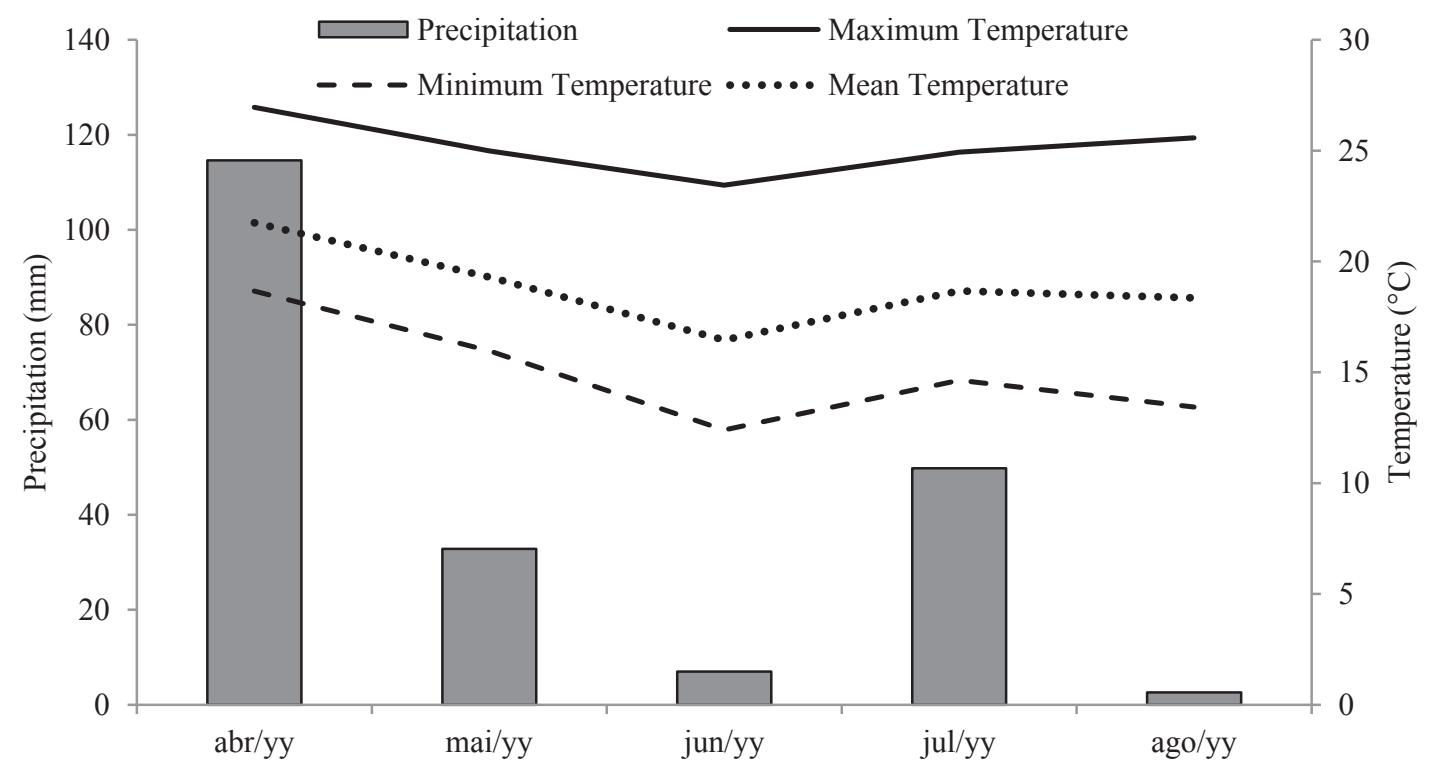

The morphological composition, forage mass and nutritive value of two elephantgrass clones (BRS Kurumi, which has a small size, and CNPGL 00-13 , which has an intermediate size) were evaluated.
The evaluations started in April and extended until August 2010, which encompassed four grazing cycles (Cycle 1 = April 22 to May 16, 2010; Cycle 2 = May 17 to June 10, 2010; Cycle $3=$ June 11 to 
July 12, 2010; and Cycle 4 = August 05 to August $28,2010)$. Grazing was interrupted from July 12 to August 5 due to low forage mass produced, which did not allow the animals to be kept in the area.

The clones were planted as seedlings in grooves $15 \mathrm{~cm}$ deep and spaced $60 \mathrm{~cm}$ apart. At planting, simple superphosphate was applied at a dose of 100 $\mathrm{kg} \mathrm{ha-1}$ of $\mathrm{P}_{2} \mathrm{O}_{5}$. Liming was done 90 days before planting using dolomitic limestone to raise the base saturation to $60 \%$. The pastures were fertilized with $150 \mathrm{~kg} \mathrm{ha}^{-1}$ of nitrogen in the form of ammonium sulfate and $120 \mathrm{~kg} \mathrm{ha}^{-1}$ of $\mathrm{K}_{2} \mathrm{O}$ in the form of potassium chloride; these fertilizers were applied in hauls and were divided into three portions of equal doses (March, April and May).

For each clone, seven paddocks of $900 \mathrm{~m}^{2}$ were used, totaling 14 paddocks. These paddocks were managed under rotational stocking with a defoliation interval of 24 days and four days of occupation of paddocks. Post-grazing heights of 50 and $35 \mathrm{~cm}$ were adopted for the management of CNPGL 00-13 and BRS Kurumi, respectively. Sward height was monitored by taking 60 systematic readings along four transect lines (15 readings per line) in each paddock using a stick graduated in centimeters. Readings were taken from ground level, considering the upper surface of the leaf canopy around the ruler as a reference. The variable stocking rate was used (ALLEN et al., 2011), in which extra animals were placed in the paddocks to reach the target postgrazing heights during the occupation period. The grazing was performed by 16 Holstein x Gyr heifers (eight per grass) that had an initial average weight of $150 \mathrm{~kg}$. The animals had water and mineral salt at the paddocks and were selected based on body weight and genetic composition. For this study, a completely randomized design with three replicates (paddocks) was adopted, and measurements repeated over time (grazing cycles) were used.

Forage mass was measured by cutting the vegetation within three $1.0 \times 1.0-\mathrm{m}$ frames per paddock positioned to represent sward conditions at the time of sampling based on average height. Samples were collected every week at ground level. After cutting, the samples were taken to the laboratory for weighing and separation into leaf lamina, stem (stems + leaf sheaths) and dead material. After separation, the samples were dried at $55^{\circ} \mathrm{C}$ in a forced-air oven until constant weight, and the results were used to obtain the dry mass of the different components of the vegetation as well as the leaf:stem ratio.

For nutritive value determinations, samples were manually collected at the proposed post-grazing height in accordance with the methods of Cóser et al. (2003). The samples were taken from three selected tussocks in each paddock, one day before grazing. The forage samples from each clone were weighed, pre-dried in a forced-air circulation oven at $55^{\circ} \mathrm{C}$, ground in a Wiley mill equipped with a $1-\mathrm{mm}$ mesh screen, and stored in labeled plastic containers for laboratory analyses. The following methods were used for chemical analysis: dry matter (DM) was obtained after oven drying at $105^{\circ} \mathrm{C}$, ash was obtained after oven drying at $600^{\circ} \mathrm{C}$ for $2 \mathrm{~h}$, and crude protein contents were analyzed following the Kjeldahl procedure described by the Association of Official Analytical Chemists (2000) and calculated as $\mathrm{N} \times 6.25$. Neutral detergent fiber, acid detergent fiber and lignin were assayed using the procedures described by Van Soest et al. (1991) without the use of $\alpha$-amylase. The in vitro dry matter digestibility (IVDMD) was obtained according to the procedures described by Tilley and Terry (1963).

An analysis of variance was performed on the non-transformed data using the MIXED procedure of SAS version 9.0, which is specific for measurements repeated over time and for when time is both a factor and a potential cause of variation. The choice of the covariance matrix was made based on the Akaike information criterion (AIC). The analysis was performed considering clone, grazing cycle and their interaction as fixed effects and experimental error between units and the error for the same units over time as random effects. 
The means were estimated using the LSMEANS statement, and comparisons made with Student's $t$-test at the $5 \%$ significance level.

\section{Results and Discussion}

The pre- and post-grazing canopy heights differed according to the clones and grazing cycles, and there was no interaction between these factors.

The average pre-grazing canopy heights were $72.7 \mathrm{~cm}$ and $57.6 \mathrm{~cm}$ for the CNPGL 00-1-3 and BRS Kurumi clones, respectively. For the post-grazing height, a mean value of $54.8 \mathrm{~cm}$ was obtained for CNPGL 00-1-3, and $43.7 \mathrm{~cm}$ was obtained for BRS Kurumi. The value observed for CNPGL 00-1-3 was close to the intended height $(50 \mathrm{~cm})$, whereas for BRS Kurumi the post-grazing residue height was slightly above the recommended $35 \mathrm{~cm}$.
The significantly higher pre- and post-grazing values $(\mathrm{P}<0.001)$ observed for the CNPGL 00-1-3 clone are due to its intermediate size and higher rate of stem elongation in comparison with BRS Kurumi, which is a dwarf clone, as reported by Fernandes et al. (2016). The post-grazing height obtained for both clones indicates the greater ease of the maintenance of the structure of these materials compared to the tall cultivars of elephantgrass, such as Napier and Cameroon.

With the increasing sequence of grazing cycles, there was a reduction $(\mathrm{P}<0.05)$ in the pre- and postgrazing heights (Table 1) due to the unfavorable climatic conditions of the dry season. The small increase in post-grazing height observed in the fourth cycle can be attributed to the interruption of the experiment during the month of July, as described previously, and to the lower grazing pressure due to the low forage allowance.

Table 1. Pre and post-grazing heights $(\mathrm{cm})$ of elephantgrass clones as a function of the grazing cycle.

\begin{tabular}{lccccc}
\hline \multirow{2}{*}{ Height } & \multicolumn{4}{c}{ Grazing cycles } & \multirow{2}{*}{ SEM $^{(\mathbf{1})}$} \\
\cline { 2 - 5 } & Cycle 1 & Cycle 2 & Cycle 3 & Cycle 4 & 2.82 \\
Pre-grazing & $75.0 \mathrm{a}$ & $68.1 \mathrm{ab}$ & $58.1 \mathrm{~b}$ & $59.3 \mathrm{~b}$ & 2.83 \\
Pos-grazing & $56.9 \mathrm{a}$ & $48.3 \mathrm{~b}$ & $43.2 \mathrm{c}$ & $47.9 \mathrm{bc}$ & 1.83 \\
\hline
\end{tabular}

Means in the same rows followed by the same letter do not differ $(\mathrm{P}<0.05)$ by " $\mathrm{t}$ " test of "Student" ("PDIFF"). (1)Standard error of the mean.

Green forage mass was influenced by clone factors $(\mathrm{P}=0.047)$ and grazing cycle $(\mathrm{P}=0.006)$, but there was no interaction between these factors $(\mathrm{P}=0.097)$. The average green forage mass of clone CNPGL 00-1-3 was 2,715 $\mathrm{kg} \mathrm{ha}^{-1}$; this value was $17 \%$ higher than that of BRS Kurumi, whose average was $2,320 \mathrm{~kg} \mathrm{ha}$. According to Mello et al. (2002), canopy height data indicate that the selection of elephantgrass plants based on forage mass production should be related to taller plants regardless of the season of the year. This may explain the observed results, since the CNPGL 00-1-3 clone is intermediate in size and the BRS Kurumi clone is a dwarf type.
A reduction in the dry mass of green forage was observed as a function of grazing cycle. The highest values were obtained in the first cycle $(3,060 \mathrm{~kg}$ ha $\left.{ }^{1}\right)$. There were no differences in values between the other cycles; average values of 2,491, 2,446 and $2,073 \mathrm{~kg} \mathrm{ha}^{-1}$ for cycles 2, 3 and 4, respectively, were observed. This response reflects the unfavorable environmental and climatic conditions of the dry season. These conditions are related to factors such as low temperature, unfavorable photoperiod or reduced nutrient availability, which normally occur under water limited conditions.

Leaf mass was influenced only by grazing cycle 
$(\mathrm{P}<0.001)$ (Table 2). Mean values of 810 and 909 $\mathrm{kg} \mathrm{ha}^{-1}$ of leaf mass were observed in each grazing cycle for clones CNPGL 00-1-3 and BRS Kurumi, respectively, representing, on average, $32.7 \%$ and $40.4 \%$ of the green forage mass, respectively.

The highest values of leaf mass were obtained in the first cycle, but they gradually decreased until the third cycle. The leaf mass increased in the fourth grazing cycle; however, the values did not differ from those obtained in the second cycle. This finding was probably due to the interruption of grazing due to the low supply of forage during the month of July, which provided better conditions for pasture regrowth.

Table 2. Dry mass of leaves $\left(\mathrm{kg} \mathrm{ha}^{-1}\right)$ of elephantgrass clones as a function of the grazing cycle.

\begin{tabular}{ccccc}
\hline \multicolumn{4}{c}{ Grazing cycles } & \multirow{2}{*}{ SEM $^{(1)}$} \\
\hline Cycle 1 & Cycle 2 & Cycle 3 & Cycle 4 & \\
\hline $1,377 \mathrm{a}$ & $785 \mathrm{~b}$ & $409 \mathrm{c}$ & $866 \mathrm{~b}$ & 152.7 \\
\hline
\end{tabular}

Means followed by the same letter do not differ $(\mathrm{P}<0.05)$ by " $\mathrm{t}$ " test of "Student" ("PDIFF"). (1)Standard error of the mean.

Voltolini et al. (2008) evaluated the elephantgrass cultivar Napier managed under rotational stocking and reported an average value of $33.9 \%$ for leaf mass in relation to the total forage mass, which was between the values obtained in the present study. Although CNPGL 00-1-3 presented greater height and greater green forage mass, BRS Kurumi presented, in absolute values, the greatest proportion of leaf mass, fraction of higher nutritive value and preferably consumed by grazing animals. Gomide et al. (2015) also reported a higher proportion of leaves for BRS Kurumi compared to CNPGL 00-13 when these genotypes were evaluated during the rainy season. Fernandes (2011) reported that BRS Kurumi showed a higher dry leaf mass $(1,877 \mathrm{~kg}$ ha $^{-1}$ grazing cycle ${ }^{-1}$ ) than did CNPGL 00-1-3 in the rainy season.

Paciullo et al. (2003) reported leaf mass values of $608.5 \mathrm{~kg} \mathrm{ha}^{-1}$ for the elephantgrass cultivar Napier in the dry season of the year. Lopes et al. (2003) studied the cultivar Napier managed under rotational stocking (including a 30-day of rest period) and reported an average value of $963 \mathrm{~kg} \mathrm{ha}^{-1}$ of forage mass for the months of April to August. Thus, the values obtained in the present study reinforce the high productive potential of smallsized elephantgrass clones, even during periods of unfavorable growth.

Stem dry mass was influenced by the interaction $(\mathrm{P}=0.018)$ between grazing cycle and clone (Table 3). Differences between clones were observed only in the first and third cycles. The difference obtained in the first cycle is probably due to the better growth conditions, since the difference occurred in the transition of the rainy season to the drought season, contributing to the higher proportion of stems in clone CNPGL 00-1-3, which presents an intermediate size. The same results were observed by Gomide et al. (2015) during the rainy season. According to these authors, the higher stem mass of clone CNPGL 00-1-3 contributed to its lower leaf:stem ratio observed in relation to that of BRS Kurumi. However, Fernandes (2011) did not observe differences in the dry mass of stems of clones CNPGL 00-1-3 and BRS Kurumi when evaluated in the rainy period. 
Table 3. Dry mass of stem $\left(\mathrm{kg} \mathrm{ha}^{-1}\right)$ of elephantgrass clones as a function of the grazing cycle.

\begin{tabular}{|c|c|c|c|c|c|}
\hline \multirow{2}{*}{ Clones } & \multicolumn{4}{|c|}{ Grazing cycles } & \multirow{2}{*}{ SEM $^{(1)}$} \\
\hline & Cycle 1 & Cycle 2 & Cycle 3 & Cycle 4 & \\
\hline CNPGL 00-1-3 & $2,012 \mathrm{aA}$ & $1,037 \mathrm{bA}$ & $2,504 \mathrm{aA}$ & $1,101 \mathrm{bA}$ & \multirow{2}{*}{186.3} \\
\hline BRS Kurumi & $1,353 \mathrm{aB}$ & $1,408 \mathrm{aA}$ & $1,569 \mathrm{aB}$ & $1,029 \mathrm{aA}$ & \\
\hline
\end{tabular}

Means followed by the same lowercase letter on the line and by the same capital letter in the column do not differ $(\mathrm{P}<0.05)$ by " $\mathrm{t}$ " test of "Student" ("PDIFF"). ${ }^{(1)}$ Standard error of the mean.

The difference observed in the third cycle was unexpected, since both clones were subjected to the same growth conditions. Problems in adjusting grazing pressure or in pasture sampling may have contributed to these results. Fernandes (2011) reported differences in stem mass in the same clones as a function of the cycle during the rainy season.

The proportions of stem mass in relation to green forage mass observed for clones CNPGL 00-1-3 and BRS Kurumi were $67.2 \%$ and $59.6 \%$, respectively, corresponding to an average yield of 1,664 and 1,340 $\mathrm{kg} \mathrm{ha}^{-1}$ cycle $^{-1}$ for the respective clones. Voltolini et al. (2008) observed a proportion of $63.5 \%$ of stem mass in the total forage mass during the rainy season when evaluating the elephantgrass cultivar Napier.

Dry mass of dead forage was not influenced by clone $(\mathrm{P}=0.63)$ or grazing cycle $(\mathrm{P}=0.084)$. The proportion of dead forage mass represented approximately $24 \%$ of the dry mass of forage. Gomide et al. (2015) reported that the proportions of dead material for both clones were less than $10 \%$ of the DM during the rainy season. Fernandes (2011) also evaluated the same clones under grazing during the rainy season and reported lower values than those obtained in the present study, with averages of 434 and $209 \mathrm{~kg} \mathrm{DM}^{-1}$ cycle $^{-1}$ for clones CNPGL 00-1-3 and BRS Kurumi, which correspond to an average proportion of $10 \%$ of the dry mass of dead material in relation to the total forage mass. These proportions are smaller than those observed in the present work, which may be due to the lower production of new leaves and, consequently, an increase in the proportion of senescent material due to the influence of the dry season weather.

The leaf:stem ratio was influenced only by the grazing cycle $(\mathrm{P}<0.001)$ (Table 4$)$. Leaf:stem ratios of 0.61 and 0.77 were observed for clones CNPGL 00-1-3 and BRS Kurumi, respectively. The increase in the leaf:stem ratio observed in the fourth cycle corroborates the significant increase in leaf dry mass values (Table 2). Both events can be attributed to the interruption of the experiment due to the low forage allowance during the month of July. Gomide et al. (2015) evaluated the same clones and obtained values of 1.34 and 0.96 for the leaf:stem ratio, and the highest values were observed for the BRS Kurumi clone during the rainy season.

Table 4. Leaf:stem ratio of elephantgrass clones as a function of the grazing cycle.

\begin{tabular}{ccccc}
\hline \multicolumn{4}{c}{ Grazing cycles } & \multirow{2}{*}{ SEM(1) $^{(\mathbf{1})}$} \\
\hline Cycle 1 & Cycle 2 & Cycle 3 & Cycle 4 & 0.09 \\
\hline $1.00 \mathrm{a}$ & $0.67 \mathrm{~b}$ & $0.25 \mathrm{c}$ & $0.85 \mathrm{ab}$ & 0 \\
\hline
\end{tabular}

Means followed by the same letter do not differ $(\mathrm{P}<0.05)$ by "t" test of "Student" ("PDIFF"). ${ }^{(1)}$ Standard error of the mean. 
The low leaf:stem ratio observed in the third cycle can be explained by the stem elongation of the newly formed internode cells in response to the flowering process observed during that time. From the point of view of animal nutrition, the high leaf:stem ratio is of great importance, not only because of the higher quality of the leaves in relation to the stem but also because of the preference of the animals to consume more leaves than stems during grazing (MELLO et al., 2002).

The content of crude protein (CP) was not influenced by the factors studied, with average values of $15.3 \%$ and $15.8 \%$ PB for the CNPGL 00-1-3 and BRS Kurumi clones, respectively. Madeiro (2010) evaluated these clones managed under rotational stocking in the transition seasons (rainy/dry) and observed no differences between the clones. This author reported values of $20.4 \%$ and $20.5 \%$ of CP, for the CNPGL 00-1-3 and BRS Kurumi clones, respectively. The lower values obtained in the present work could be attributed to the unfavorable growth conditions during the dry period. Pereira et al. (2013) reported average values of $12.1 \%$ and $17.3 \%$ of CP for the CNPGL 00-13 and BRS Kurumi clones, respectively, grazed under IL-light interceptation (95\%) during the rainy season. Lopes et al. (2003) reported an average value of $11.7 \%$ of CP for the elephantgrass cultivar Napier managed under rotational stocking (30 days of rest and three days of occupation) from April to September. Deresz (2001) and Carvalho et al. (2005) observed mean values of $12.7 \%$ and $13.0 \%$ $\mathrm{CP}$, respectively, for the elephantgrass cultivar
Napier managed in a rotational stocking system during the rainy season. The observed $\mathrm{CP}$ contents of clones can be considered high, including both contents obtained in the present study as well as those reported by Madeiro (2010) and Pereira et al. (2013), except for the value described by the latter authors for clone CNPGL 00-1-3.

Neutral detergent fiber (NDF) and in vitro dry matter digestibility coefficients (IVDMD) wereinfluenced only by grazing cycle, and no interactions of the factors studied were observed (Table 5). Values of $55.2 \%$ and $53.9 \%$ of NDF for the CNPGL 00-1-3 and BRS Kurumi clones, respectively, were observed. Evaluating the same elephantgrass clones in the transition period, Madeiro (2010) reported an average value of 53.3\% for NDF content. However, Pereira et al. (2013) obtained higher mean values of $60 \%$ NDF for both clones during the rainy season under grazing using 95\% light interception by the canopy as a criterion for regrowth interruption. The highest NDF values were observed in the first grazing cycle $(\mathrm{P}<0.001)$, and a lower content was obtained in the fourth cycle (Table 5), which may have occurred due to the interruption of grazing due to the low forage allowance during the month of July. This low forage allowance provided better conditions for plant growth, which is reflected by the reduction in NDF in the fourth cycle. However, there are reports that plants subjected to water stress had lower contents of plant cell walls (HALIM et al., 1989), which may have contributed to the lower NDF content observed in the fourth cycle.

Table 5. Contents of neutral detergente fiber (NDF) and in vitro dry matter digestibility (IVDMD) coefficient of elephantgrass clones as a function of the grazing cycle

\begin{tabular}{|c|c|c|c|c|c|}
\hline \multirow{2}{*}{ Variable } & \multicolumn{4}{|c|}{ Grazing cycles } & \multirow{2}{*}{ SEM $^{(2)}$} \\
\hline & Cycle 1 & Cycle 2 & Cycle 3 & Cycle 4 & \\
\hline $\mathrm{NDF}^{(1)}$ & $55.5 \mathrm{a}$ & $56.0 \mathrm{a}$ & $55.7 \mathrm{a}$ & $50.9 \mathrm{~b}$ & 0.62 \\
\hline $\operatorname{IVDMD}^{(1)}$ & $70.5 \mathrm{ab}$ & $69.1 \mathrm{~b}$ & $67.5 \mathrm{c}$ & $71.7 \mathrm{a}$ & 0.63 \\
\hline
\end{tabular}

Means in the same rows followed by the same letter do not differ $(\mathrm{P}<0.05)$ by "t" test of "Student" ("PDIFF"). (1)Dry matter basis. ${ }^{(2)}$ Standard error of the mean. 
The clones did not differ $(\mathrm{P}=0.34)$ with respect to the IVDMD coefficient, and values of $69.4 \%$ and $70.0 \%$ were obtained for clones CNPG 001-3 and BRS Kurumi, respectively. The DIVMS values obtained for both were superior to those described by Carvalho et al. (2005), who studied the morphophysiological characteristics and quality of the elephantgrass cultivar Napier; Lima et al. (2008), who evaluated the composition and IVDMD of elephantgrass genotypes; and Lopes et al. (2005), who studied the elephantgrass cultivar Napier managed under rotational stocking with different rest periods (30 to 45 days). Studying the same clones in the rainy-to-dry-season transition period (April to June 2009), Madeiro (2010) also did not observe differences between clones CNPGL 00-1-3 and BRS Kurumi and reported respective values of $73.8 \%$ and $72.7 \%$, which are close to those obtained in the present study, evidencing the high nutritional potential of these genotypes. Regarding the variation in IVDMD as a function of grazing cycle $(\mathrm{P}=0.002)$, there was a decrease in the values up to the third cycle, and an increase in the fourth cycle was also observed, with a value similar to that obtained in the first cycle (Table 5). This result is most likely due to the improvement of the regrowth conditions of the plants from the third to the fourth cycle, as previously reported.

The lignin contents did not vary $(\mathrm{P}>0.05)$ with clone, grazing cycle or their interactions, and the mean values were 3.5 and $4.1 \%$ for CNPGL 001-3 and BRS Kurumi, respectively. These values were lower than those reported by Morenz et al. (2012) with Napier grass managed under rotational stocking with a rest period of 30 days during the rainy season. Also, lignin contents varying from 5.1 to $7.6 \%$ were related to different elephantgrass cultivars (LIMA et al., 2008; VOLTOLINI et al., 2010; MORENZ et al., 2012). The results reported in the present study confirm the low lignin contents found by Madeiro (2010), who evaluated the same elephantgrass clones in the previous year.
High CP contents associated with low fiber contents resulted in high digestibility coefficients, indicating high nutritive value of the clones with management under grazing, even during the dry season of the year. However, the low forage mass during the dry period of the year due to the unfavorable climatic conditions should be considered when planning the feeding of cattle throughout the year.

\section{Conclusions}

The clones are similar in terms of agronomic characteristics and nutritive value during the dry period.

The high protein content and low NDF content indicate that clones can be an important source of nutrients for animals even in the dry season.

\section{References}

ALLEN, V. G.; BATELlO, C.; BERETTA, E. J.; HODGSON, J.; KOTHMANN, M.; LI, X.; McIVOR, J.; MINE, J.; MORRIS, C.; PEETERS, A.; SANDERSON, M. An international terminology for grazing lands and grazing animals. Grass and Forage Science, Chichester, v. 66, n. 1, p. 2-28, 2011.

ASSOCIATION OF OFFICIAL ANALYTICAL CHEMISTS - AOAC. Official methods of analysis. $19^{\text {th }}$ ed. Washington: 2000. 1219 p.

CARVAlHO, C. A. B.; DERESZ, F.; ROSSIELlO, R. O. P.; PACIULLO, D. S. C. Influência de intervalos de desfolha e de alturas do resíduo pós-pastejo sobre a produção e a composição da forragem e do leite em pastagens de capim-elefante. Boletim da Indústria Animal, Nova Odessa, v. 62, n. 3, p. 177-188, 2005.

CHAVES, C. S.; RIBEIRO, K. G.; GOMIDE, C. A. M.; PACIULLO, D. S. C.; MORENZ, M. J. F.; GAMA, D. $\mathrm{S}$. Valor nutritivo e cinética de degradação in vitro de genótipos de capim-elefante (Penissetum purpureum Schumach) sob dois intervalos de desfolhação e duas alturas de resíduo pós-pastejo. Arquivo Brasileiro de Medicina Veterinária e Zootecnia, Belo Horizonte, v. 68, n. 5, p. 1351-1359, 2016. 
CÓSER, A. C.; MARTINS, C. E.; DERESZ, F.; FREITAS, A. F.; PACIULLO, D. S. C.; SALVATI, J. A.; SCHIMIDT, L. T. Métodos para estimar a forragem consumível em pastagem de capim-elefante. Pesquisa Agropecuária Brasileira, Brasília, v. 38, n. 7, p. 875-879, 2003.

DERESZ, F. Produção de leite de vacas mestiças Holandês x Zebu em pastagem de capim-elefante, manejada em sistema rotativo com e sem suplementação durante a época das chuvas. Revista Brasileira de Zootecnia, Viçosa, MG, v. 30, n. 1, p. 197-204, 2001.

DERESZ, F.; PAIM-COSTA, M. L.; CÓSER, A. C.; MARTINS, C. E.; ABREU, J. B. R. Composição química, digestibilidade e disponibilidade de capim-elefante cv. Napier manejado sob pastejo rotativo. Revista Brasileira de Zootecnia, Viçosa, MG, v. 35, n. 3, p. 863-869, 2006.

EMPRESA BRASILEIRA DE PESQUISA AGROPECUÁRIA - EMBRAPA. Centro nacional de pesquisa de solos. Sistema brasileiro de classificação de solos. 2. ed. Rio de Janeiro: Embrapa, 2006. 306 p.

FERNANDES, P. B. Morfogênese, características produtivas e nutricionais e desempenho animal em pastos de capim-elefante anão manejados sob lotação intermitente. 2011. Dissertação (Mestrado em Zootecnia) - Universidade Federal Rural do Rio de Janeiro, Seropédica.

FERNANDES, P. B.; CARVALHO, C. A. B.; PACIULLO, D. S. C.; GOMIDE, C. A. M.; MORENZ, M. J. F.; LÉDO, F. J. S. Morphogenetic and structural characteristics of clones of elephant grass managed under intermittent stocking. Semina: Ciências Agrárias, Londrina, v. 37, n. 4, p. 2099-2110, 2016.

GOMIDE, C. A. M.; CHAVES, C. S.; RIBEIRO, K. G.; SOlleNBERGER, L. E.; PACIULlO, D. S. C.; PEREIRA, T. P.; MORENZ, M. J. F. Structural traits of elephant grass (Pennisetum purpureum Schum.) genotypes under rotational stocking strategies. African Journal of Range \& Forage Science, Hilton, v. 32, n. 1, p. 51-57, 2015.

HALIM, R. A.; BUXTON, D. R.; HATTENDORF, M. J.; CARLSON, R. E. Water-stress effects on alfalfa forage quality after adjustment for maturity differences. Agronomy Journal, Madison, v. 81, n. 2, p. 189-194, 1989.

LIMA, E. S.; SILVA, J. F. C.; VÁSQUEZ, H. M.; ARAÚJO, S. A. C.; LISTA, F. N.; CARNEIRO, R. F. V.; ROCHA, T. C.; RUIVO, S. C.; DEMINICIS, B. B.; COSTA, D. P. B. Composição e digestibilidade in vitro de genótipos de capim-elefante, aos 56 dias de rebrota. Archivos de Zootecnia, Córdoba, v. 57, n. 218, p. 279282, 2008.
LOPES, F. C. F.; AROEIRA, L. J. M.; RODRIGUEZ, N. M.; DERESZ, F.; SAMPAIO, I. B. M.; BORGES, I.; MALDONADO-VASQUEZ, H.; VITTORI, A. Degradação ruminal in situ do capim-elefante (Pennisetum purpureum, Schumack) consumido sob pastejo por vacas mestiças Holandês x Zebu em lactação. Arquivo Brasileiro de Medicina Veterinária e Zootecnia, Belo Horizonte, v. 55, n. 6, p. 694-701, 2003.

LOPES, R. S.; FONSECA, D. M.; OLIVEIRA, R. A.; ANDRADE, A. C.; NASCIMENTO JÚNIOR, D.; MASCARENHAS, A. G. Efeito da irrigação e adubação na disponibilidade e composição bromatológica da massa seca de lâminas foliares de capim-elefante. Revista Brasileira de Zootecnia, Viçosa, MG, v. 34, n. 1, p. 2029, 2005.

MADEIRO, A. S. Avaliação de clones de capim-elefante manejados sob lotação rotacionada. 2010. Dissertação (Mestrado em Zootecnia) - Universidade Federal Rural do Rio de Janeiro, Seropédica.

MELLO, A. C. L.; LIRA, M. A.; DUBEUX JÚNIOR, J. C. B.; SANTOS, M. V. F.; FREITAS, E. V. Caracterização e seleção de clones de capim-elefante (Pennisetum purpureum, Schum.) na Zona da Mata de Pernambuco. Revista Brasileira de Zootecnia, Viçosa, MG, v. 31, n. 1, p. 30-42, 2002.

MORENZ, M. J. F.; SILVA, J. F. C.; AROEIRA, L. J. M.; DERESZ, F.; VÁSQUEZ, H. M.; LOPES, F. C. F.; PACIULLO, D. S. C.; TEDESCHI, L. O. Evaluation of the Cornell Net Carbohydrate and Protein System model on the prediction of dry matter intake and milk production of grazing crossbred cows. Revista Brasileira de Zootecnia, Viçosa, MG, v. 41, n. 2, p. 398-406, 2012.

PACIULLO, D. S. C.; DERESZ, F.; AROEIRA, L. J. M.; MORENZ, M. J. F.; VERNEQUE, R. S. Morfogênese e acúmulo de biomassa foliar em pastagem de capimelefante avaliada em diferentes épocas do ano. Pesquisa Agropecuária Brasileira, Brasília, v. 38, n. 7, p. 881-887, 2003.

PEREIRA, T. P.; MODESTO, E. C.; CAMPANA, L. L.; GOMIDE, C. A. M.; PACIULlO, D. S. C.; NEPOMUCENO, D. D.; CARVALHO, C. A. B.; MACEDO, R. O.; ALMEIDA, J. C. C. Comportamento diurno de novilhas em pastagens de clones de capimelefante anão. Revista Acadêmica: Ciências Agrárias e Ambientais, Curitiba, v. 11, n. 4, p. 383-394, 2013.

QUEIROZ FILHO, J. L.; SILVA, D. S.; NASCIMENTO, I. S. Produção de matéria seca e qualidade do capimelefante (Pennisetum purpureum Schum.) cultivar Roxo em diferentes idades de corte. Revista Brasileira de Zootecnia, Viçosa, MG, v. 29, n. 1, p. 69-74, 2000. 
TILLEY, J. M. A.; TERRY, R. A. A two-stage technique for the in vitro digestion of forage crops. The Journal of British Grassland Society, Chichester, v. 18, n. 2, p. 104111, 1963.

VAN SOEST, P. J.; ROBERTSON, J. B.; LEWIS, B. A. Methods for dietary fiber, neutral detergent fiber, and nonstarch polysaccharides in relation to animal nutrition. Journal of Dairy Science, Champaign, v. 74, n. 10, p. 3583-3597, 1991.

VOLTOLINI, T. V.; SANTOS, F. A. P.; MARTINEZ, J. C.; CLARINDO, R. L.; PENATI, M. A.; IMAIZUMI,
H. Características produtivas e qualitativas do capimelefante pastejado em intervalo fixo ou variável de acordo com a interceptação da radiação fotossinteticamente ativa. Revista Brasileira de Zootecnia, Viçosa, MG, v. 39, n. 5, p. 1002-1010, 2010.

VOLTOLINI, T. V.; SANTOS, F. A. P.; MARTINEZ, J. C.; IMAIZUMI, H.; PIRES, A. V.; PENATI, M. A. Metabolizable protein supply according to the NRC (2001) for dairy cows grazing elephant grass. Scientia Agricola, Piracicaba, v. 65, n. 2, p. 130-138, 2008. 
